\title{
PERINATAL LESSONS FROM THE PAST
}

\section{Francis Glisson (1597-1677) and the "discovery" of rickets}

\author{
Peter M Dunn
}

Born in 1597, Francis was the second son of William Glisson of Rampisham of Dorset. Admitted to Caius College, Cambridge in 1617, he took a degree in Arts in 1620, was incorporated MA at Oxford in 1627, and turning to the study of physics, graduated MD from Cambridge in 1634. That same year he was admitted to the College of Physicians, becoming a fellow the following year. In 1636 he was appointed regius professor of physics at Cambridge, a post he held until his death 41 years later.

During the Civil War, he moved to loyalist Colchester, where he practised medicine with great reputation and was present during the siege by parliamentary forces in 1648 . Shortly afterwards he went to live in London and became very active in the affairs of the College of Physicians (fig 1), holding, successively, the posts of censor, councillor and president $(1667-9) .^{12}$

Soon after arriving in London, Glisson joined a small group of distinguished doctors and scientists who met weekly to discuss natural and experimental philosophy. This group, with additional members, became the Royal Society after the Restoration. In 1650 Glisson published a treatise De Rachitide, acknowledging the help of seven other physicians belonging to the group. An English edition, edited by Nicholas Culpeper (1616-54), with the title $A$ treatise of the rickets, being a disease common to children, appeared in $1651 .{ }^{3}$ Further editions appeared in 1660, 1668, 1671 and 1682 .

Glisson stated that he had been studying rickets for five years and that it was an "...absolutely new disease, and never described by any ancient or modern writers in their practical books which are extant at this day of the diseases of children. But this disease became first known about 30 years since in the counties of Dorset and Somerset ... since which time the observation of it hath been derived unto other places, as London ...."

University of Bristol Department of Child Health

Southmead Hospital Southmead Bristol BS10 5NB

P M Dunn

Correspondence to: Professor Peter Dunn.

\section{On the onset of the disease:}

"We affirm therefore, that this disease doth very rarely invade children presently after their birth, or before they are six moneths old; (yea, perhaps before the ninth moneth) but after that time it beginneth by little and little daily to rage more and more to the

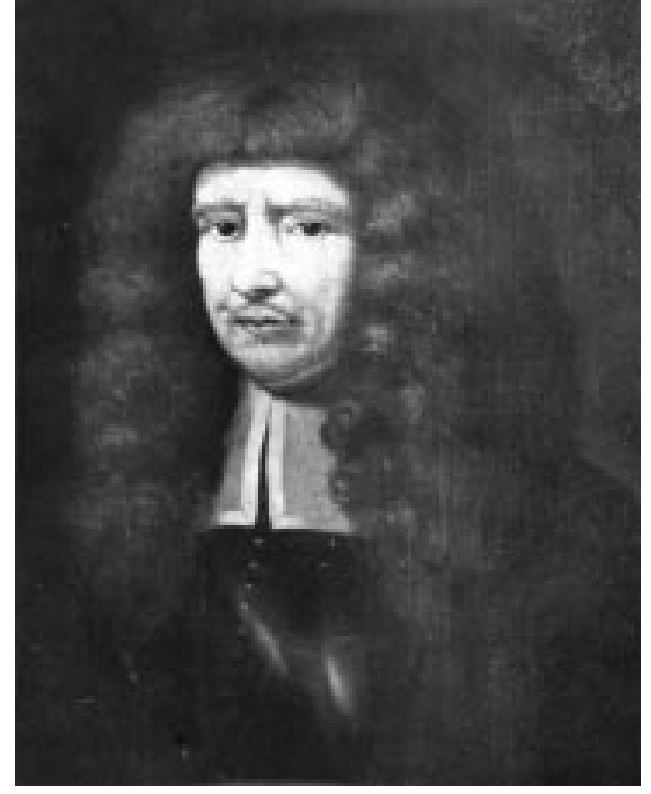

Figure 1 Francis Glisson, 1597-1677. Portrait in the Royal College of Physicians, London.

period of eighteen moneths, then is attaineth its pitch and exaltation, and as it were resteth in it, till the child be two years and six months old: so that the time of the thickest invasion is that whole year, which bears date from the eighteenth month, two years and a half being expired, the disease falleth into its declination, and seldom invadeth the child, for the reasons already alledged."

Glisson emphasised the importance of morbid anatomy in the study of this disease and, indeed, described his post mortem findings before giving a description of the clinical signs and course of the disease. He was the first to appreciate that infantile scurvy was a separate entity, although it might coexist with rickets, whereas the profession generally considered them to be one disease until Barlow's paper was published 200 years later. Glisson recognised, too, that rickets were neither congenital nor inherited, were not contagious, nor caused by syphilis. The nearest he came to a nutritional cause was to blame excessive feeding with its resulting indigestion, adding: “... and perhaps this may be reputed among the especial causes why this disease doth more frequently invade 


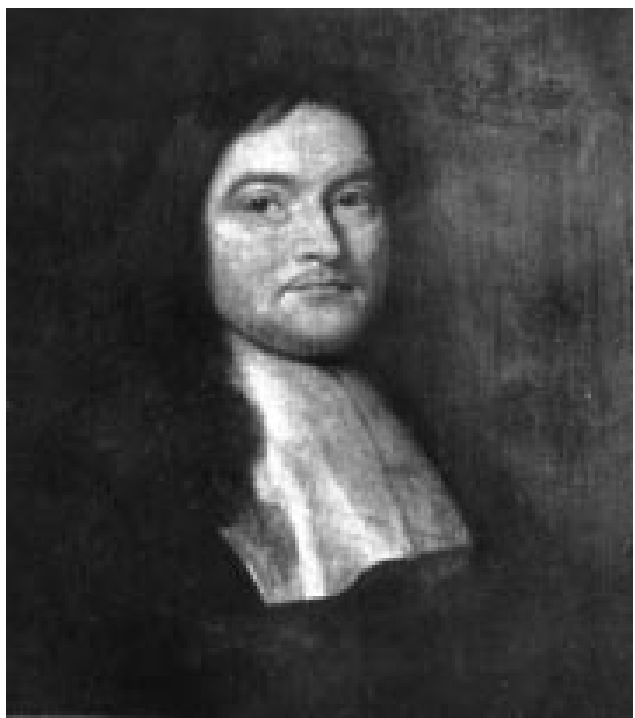

Figure 2 Daniel Whistler, 1619-84. Portrait in the Royal College of Physicians, London.

the cradles of the rich than afflict poor men's children."

While Glisson's name is primarily associated with his work on rickets, he was also a fine anatomist in the Harveian tradition, and in 1654 published a book entitled Anatomia Hepatis in which he described the sheath of the liver, known since as Glisson's capsule. ${ }^{4}$ Other books of an Arostotelian nature followed in 1672 and again in 1677 . He died on 15 October 1677, aged 81, and was buried in St Bride's Church, Fleet Street.

In fact, Glisson's text had been pre-empted by a slim thesis on rickets for the degree of MD in Leyden, delivered by Daniel Whistler in 1645. It was published that same year and describes a "syndrome of signs making in conjunction one pathognomic whole." 4 Whistler had been born in Walthamstow in 1619 and had studied at Merton College, Oxford (BA 1642; MA 1744). He gave an excellent clinical description of the disease, mentioning the enlargement of the head, the epiphyses and the abdomen, the rickety rosary and "the whole bony system ... flexible like wax that is rather liquid, so that the flabby and toneless legs scarcely sustain the weight of the superimposed body, so that the tibiae yield to the weight of the fabric pressing down on them from above and become bent; and for the same reason the thighs above are curved and the back, through the bending of the spine, projects humpfashion in the lumbar region: so they are too feeble to sit up, much less to stand, when the disease is increasing ... The teeth are cut late ... Other accompaniments are narrowness of the chest, prominence of the sternum, and asymmetry ..." ${ }^{5}$ Whistler believed that rickets had an antenatal origin due to the mother drinking too much alcohol.

After acquiring the MD at Leyden and an incorporated $\mathrm{MD}$ at Oxford, Whistler was appointed professor of geometry at Gresham College, London in 1648. He was a successful physician who shone in society and was elected a fellow of the Royal Society in 1663 . He also became a fellow of the London College of Physicians in 1649, Harveian orator in 1659, was the censor for many years, became treasurer in 1682, and "in an evil hour," president in 1683 (fig 2). It was subsequently discovered that he had neglected his duties and misappropriated College funds. He died the following year (1684) from pneumonia and was buried in the north aisle of Christ Church, Newgate Street. Although married to a rich widow, Elizabeth Lowther, he died in debt. Just before his death he had his MD thesis republished. As he was only 25 years old when it was originally presented in Leyden, there was speculation (but no evidence) that he may have had prior access to Glisson's studies on this disease.

The discovery of this new disease, rickets, in the middle of the 17 th century was probably due to the increasing urbanisation taking place at the time, as well as to misguided practices in infant feeding. Within a very short time early obstetricians like Willughby in England and van Deventer in Holland were describing the problems of delivering infants through women's rickety pelvises. Perhaps it was no coincidence that the Chamberlen family also introduced the forceps into their practice at this time and that in the 17th century man midwives increasingly invaded the previously jealously guarded female province of childbirth.

1 Munk W. The roll of the Royal College of Physicians of London. Vol. I. London: RCP, 1878.

2 Still G F. The history of paediatrics. London: Dawsons, 1965.

3 Glisson, F. A treatise of the rickets: being a disease common to children. Translated and edited by N. Culpeper. London: P. children. Trans 1651 .

4 Glisson F. Anatomia hepatis. London, 1654.

5 Whistler D. De morbo puerili Anglorum quem patrio idiomate indigenae vocant The Rickets. Leyden, 1645. 